\title{
Ethno-Edutainment Learning as an Effort to Improve Primary School Students' Spirit of Nationality
}

\author{
Savitri Wanabuliandari ${ }^{1}$, Sekar Dwi Ardianti ${ }^{2}$, Mohammad Kanzunnudin ${ }^{3}$ \\ \{savitri.wanabuliandari@umk.ac.id ${ }^{1}$, sekar.dwi.ardianti@umk.ac.id², moh.kanzunnudin@umk.ac.id³ \\ ${ }^{1}$ Mathematics Education Universitas Muria Kudus, Indonesia \\ ${ }^{2}$ Primary School Teacher Education Universitas Muria Kudus, Indonesia \\ ${ }^{3}$ Indonesian Language and Literature Education Universitas Muria Kudus, Indonesia
}

\begin{abstract}
The objectives of this research are (1) to identify the students' spirit of nationality on ethno-edutainment-based learning, and (2) to reveal the students' response towards ethno-edutainment-based learning. This research used one group pretest posttest modeling quantitative research design. The population of this research included fifth grade students at SD Muhamadiyah 1 Kudus. In this research, the sample was taken by employing purposive sampling technique. The sample of this research involved students of VA class at SD Muhamadiyah 1 Kudus. The data collection technique used in this research was non-test technique, that is,questionnaire. It was to identify the students' spirit of nationality and response towards the learning. The data were analyzed by employing normalized gain test. The result of this research showed that there was an improvement on the students' spirit of nationality.The score of n-gain of the national characteristics classically reached $64 \%$ or 0,64 , which was categorized into medium. In addition, the students' response towards Ethno-Edutainment-based learning was categorized as good.
\end{abstract}

Keywords: Ethno-Edutainment, primary school students, spirit of nationality.

\section{Introduction}

Nowadays, youth generation has been influenced by foreign cultures (westernized) infiltrating to Indonesia. Youth should not be easily influenced by foreign cultures; they have to be able to reconsider both the positive and negative impacts of those cultures. According to National Education Ministry (2010), the stronger is someone in making consideration, the stronger will he be in growing and developing as a good country citizen. When someone has many considerations in facing foreign cultures, he or she will be more selective to foreign cultures, allowing him to choose which culture is appropriate to be adopted according to his national characteristics of Indonesia.

National Education Ministry (2010) explains that characteristics consist of characters, attitudes, or personality of someone which is derived from internalization process between values, moral, and norms which are then believed and used as the basis for thinking, anticipating, and putting into action. This means that the interaction between people can grow up the characters of society, which ends up on the national character building. Kusmiarsih (2013) states good characteristics can boost the quality of youth generation, which can minimize the problems in culture and national characters. Therefore, if someone desires to develop national characters, the first thing to do is to deal with developing individual characters of each person. One of the characters which need to be built is the character of 
patriotism and spirit of nationality. In reality there are many examples regarding to the lack of nationality spirit of our youth generation, including some cases as the hunting on Cenderawasih as one of the typical animals in Indonesia, primary school student brawl, and so on. Ardianti (2017) states that character building by means of learning activity should be integrated and unified, as one of the important parts in learning process and should not stand on its own. Learning has an important role in national character building.

Based on the result of questionnaires on 10 primary school teachers at Kudus Regency, it was found that teachers had not discovered the effective way to instill spirit of nationality character in classroom learning. This result of questionnaires also showed that teachers thought they needed to instill spirit of nationality character by introducing local culture. Besides, the result of questionnaires showed that there were teachers who had not inserted the character building of spirit of nationality in learning.Thus, teachers should instill spirit of nationality character building by introducing local culture, and one of the ways is through ethno-edutainment-based learning.

Teachers are one component with very significant roles in building spirit of nationality the building of this spirit needs to be done since this country is in the need of better generation in the future. The term Ethnois derived from the word 'ethnic' which means being related to the existing common local cultures in society. D'Ambrosio (in Wahyuni, et al, 2013) clarifies that the term ethno refers to the social and cultural contexts, acting as a kind of language, jargon, behavioral code, myths, and symbols. Saepudin (2016) says that the term edutainment is derived from the words education and entertainment. Linguistically, edutainment is an education which entertains or makes learning process entertaining. It means that ethnoedutainment learning is a learning about local cultures, which is designed in an entertaining way of learning. Zafirah (2018) claims that the use of local cultures of traditional games can assist the character value building to the students. Through ethno-edutainment learning, it is expected that students can grasp better understanding, which is more impressed with local culture sstudies through entertaining learning method. Thematic learning based on ethnoedutainment is also expected to improve the students' spirit of nationality character.

\section{Research Method}

In this research, the method which was employed was pre-experimental design. The research took place at SD Muhamadiyah 1 Kudus which was located at Jl. KH Asnawi No.34, Damaran, Kota Kudus, Kabupaten Kudus, Jawa Tengah 59316. The subject of this research focused on the students of VB class at SD Muhamadiyah 1 Kudus the data collection technique in this research was non-test. Specifically, this technique utilizes observation sheet as instrument to measure the students' spirit of nationality and a questionnaire to identify the students' response towards the learning. The obtained data were then analyzed by means of normalized gain test to measure the improvement on the students' spirit of nationality. Afterwards, the data were described the narrative form.

\section{Results and Discussion}

\subsection{The Improvement on Spirit of Nationality Character}

The scores on students' spirit of nationality character were obtained from the observation during learning process and from the result of observation sheet on spirit of nationality. Both scores before and after the implementation of thematic learning based on ethno-edutainment is presented in Table 1 as follows. 
Table 1.Recapitulation of Scores on Spirit of Nationality Before and After Learning.

\begin{tabular}{ccc}
\hline \multirow{2}{*}{ Components } & \multicolumn{2}{c}{ Scores on Spirit of Nationality } \\
\cline { 2 - 3 } & Before & After \\
\hline Mean & 5,14 & 8,27 \\
Highest Score & 7 & 10 \\
Lowest Score & 3 & 7 \\
\hline
\end{tabular}

The obtained scores of students' spirit of nationality after learning were generally higher than those of before learning. It can be seen from the mean score of students' spirit of nationality character after learning which reached 8,27 . Before the learning,it was only 5,14. These scores were then analyzed statistically though normalized gain test to identify how significant is the improvement on the scores of students' spirit of nationality between before and after learning.

The calculation on the increased spirit of nationality character through normalized gain test can be seen on the Table 2 below.

Table 2.The Result of Improvement on Spirit of Nationality

\begin{tabular}{cc}
\hline Criterion & Percentage \\
\hline Low & $9,09 \%$ \\
Moderate & $54,55 \%$ \\
High & $36,36 \%$ \\
\hline
\end{tabular}

Based on the table, there was an improvement on the students' spirit of nationality character with the low improvement of $9,09 \%$, the moderate improvement of $54,55 \%$, and high improvement of $36,36 \%$. Classically, normalized gain $\langle g\rangle$ value of $64 \%$ or 0,64 was obtained, which indicated the improvement was in moderate category.

The improvement on the students' spirit of nationality was mainly caused by the implementation of thematic learning based on ethno-edutainment. The thematic learning based on ethno-edutainment involved components of local cultures which were correlated with learning materials in thematic manner. The involvement of students' local culturein learning can instill positive characters towards the students since most of the local cultures of Indonesia have their typical national characters. This is in line witha research conducted by Hasanah (2016) that insights on local cultures can develop the students' potentials and can instill characters to the students.

Ethno-edutainment-based learning engages students to learn directly in the entertaining environment and. Thematic learning based on ethno-edutainment can assist teachers in inserting character building in his or her lessons. Ardianti, et al (2019) states that learning which is designed in an interesting and entertaining way is appropriate to be employed by primary school teachers when instilling character values since one of the basic natures of primary school students is the tendency of playing around. Learning experiences acquired directly by the students contribute positive effects towards the improvement on the spirit of nationality character of the students.As seen on Table 1, the mean score of students' spirit 
nationality after learning is higher than that before learning. The result of normalized gain test also showed that $54,55 \%$ of the whole students made improvements on the scores of spirit of nationality to moderate category. This improvement occurred because of the implementation of ethno-edutainment-based learning. Lestyarini (2012) clarifies that integrated learning which lies on philosophical-historical understanding about Indonesia and based on local wisdom improves the spirit of nationality which grows to strengthen Indonesian's characters. The spirit of nationality is one of the foundations to strengthen this Indonesian character.

\subsection{Students' Responses}

Data related to students' responses were obtained by examining questionnaire on students' responses at the end of ethno-edutainment-based learning. The indicators used in students' response questionnaire included students' interest in the learning method, the improvement on the spirit of nationality character, the improvement on the activity during the current learning activities, as well as the ease of students in understanding the taught concepts during ethno-edutainment-based learning. The result of analysis of students' responses can be seen in the Table 3 as follows.

Table 3. Students' Perception towards Ethno-Edutainment-based Learning

\begin{tabular}{clc}
\hline No & \multicolumn{1}{c}{ Statement } & $\begin{array}{c}\text { Answer } \\
\text { Yes (\%) }\end{array}$ \\
\hline 1 & $\begin{array}{l}\text { Interest in ethno-edutainment-based learning. } \\
2\end{array}$ & $\begin{array}{l}\text { Ethno-edutainment-based learning can improve students' spirit of } \\
\text { nationality character }\end{array}$ \\
3 & $\begin{array}{l}\text { Ethno-edutainment-based learning can improve the students' } \\
\text { activeness }\end{array}$ & 81,82 \\
4 & $\begin{array}{l}\text { Ethno-edutainment-based learning can ease the students' understanding } \\
\text { towards taught concepts }\end{array}$ & 86,36 \\
\hline
\end{tabular}

Table 3 shows the result of students' responses towards ethno-edutainment-based learning. In general, students gave positive responses towards the thematic learning based on ethno-edutainment. This learning is a learning which involves surrounding local wisdom and excellences which are correlated with the learning materials, and well designed to become interesting and enjoyable learning activity. As primary school students still have the nature of playing around, the learning process that is designed within an interesting activity will arouse the students' interest in learning. Indriati (2012) argues that edutainment learning encourages students to learn while playing in small groups so that they get interested and, as a result, experience no boredom. In addition, through playful activities, students do not only acquire certain knowledge, but the other ways of thinking will be built within his ideas and behavior. It is in accordance with the result of students' questionnaire, that is, the entire students showed their interest in ethno-edutainment-based learning. This finding is in line with that of Ardianti, et al (2019) that students are interested in learning with materials which are equipped with stories, images, and enjoyable activities.

The result of students' responses also showed that up to $81,82 \%$ of the students stated that thematic learning based on ethno-edutainment can improve their spirit of nationality character. This is also in accordance with the result of normalized gain test on the data about improvement on students' spirit of nationality character. Wanabuliandari (2016) says that through local cultures, teachers are easier to instill characters. The result of the questionnaire 
also indicated that up to $81,82 \%$ of the students claimed that it was easy to understand learning concepts through ethno-edutainment-based learning method. This is because ethnoedutainment-based learning involves students' surrounding cultures so that it makes the learning more real. Wanabuliandari et al (2016) claims that through a real-life learning can get students engaged more actively in learning and thus obtain deeper understanding of the taught materials. Asriati (2012) argues that learning process which involves local excellences is in line with the existing environment which is experienced directly by students so that real-lifebased learning can create meaningful learning process. Students do not feel difficult in grasping the concepts which are correlated with the surrounding real conditions.

\section{Conclusion}

The implementation of ethno-edutainment-based learning can improve students' spirit of nationality. This improvement on spirit of nationality is derived from the score of normalized

gain $\langle g\rangle$ of $64 \%$ or 0,64 which means that the spirit of nationality is in moderate category. The students' responses towards thematic learning based on ethno-edutainment are in good category.

\section{Acknowledgements}

The researchers would like to express their appreciation to the side of SD 1 Muhammadiyah who has given permissions to conduct this research. The other gratitude goes to the rector of Muria Kudus University and The Research Board of Muria Kudus University who have made this research possible. 


\section{References}

[1] Ardianti,S.D., Wanabuliandari,S., \& Rahardjo,S.: Peningkatan Perilaku Peduli Lingkungan dan Tanggung Jawab Siswa Melalui Model EJAS dengan Pendekatan Science Edutainment. Vol. 4 (1) pp. 1-7. Jurnal Ilmiah Pendidikan Dasar (2017)

[2] Ardianti, S. D., Wanabuliandari, S., \& Kanzunnudin, M.: Implementasi Pembelajaran Berbasis Ethno-Edutainment Untuk Meningkatkan Karakter Cinta Tanah Air Siswa Sekolah Dasar. Vol. 9(2) pp. 204-209. Refleksi Edukatika: Jurnal Ilmiah Kependidikan (2019)

[3] Ardianti, S.D., Wanabuliandari, S., Saptono, S., \& Alimah, S.: A Need Assesment of Edutainment Module With Ethnoscience Approach Oriented to the Love of the Country. Vol. 8(2) pp. 153-161. Jurnal Pendidikan IPA Indonesia (2019)

[4] Arfianawati,S., Sudarmin, \& Sumarni, W.: Model Pembelajaran Kimia Berbasis Etnosains untuk Meningkatkan Kemampuan Berpikir Kritis Siswa. Vol. 21(1). Jurnal Pengajaran MIPA (2016)

[5] Saepudin, A., Saluky, S., \& Misri, M.A.: The Use Effects Of Interactive Multimedia Edutainment On The Achievement Improvements In Mathematics. Vol. 1(1) pp. 1-15. Information Technology Engineering Journals (2016)

[6] Hake, R.R.: 1998. Interactive-engagement versus traditional methods: A six-thousandstudent survey of mechanics test data for introductory physics courses. Vol. 66(1) pp. 64-74. American Journal of Physics (1998)

[7] Hasanah, D. \& Prihati,Y.: Pengembangan Modul Fisika Berbasis Potensi Lokal Kerajinan Gerabah Kasongan Yogyakarta Pada Materi Usaha Dan Energi Untuk Siswa SMA. Prosiding Seminar Nasional Pendidikan Sains: Peningkatan Kualitas Pembelajaran Sains dan Kompetensi Guru melalui Penelitian \& Pengembangan dalam Menghadapi Tantangan Abad-21. Surakarta (2016)

[8] Kementrian Pendidikan Nasional, Badan Penelitian dan Pengembangan Pusat Kurikulum: Bahan Pelatihan Penguatan Metodologi Pembelajaran 127 Berdasarkan Nilai-Nilai Budaya Untuk Membentuk Daya Saing Dan Karakter Bangsa. Pengembangan Pendidikan dan Karakter Bangsa. Jakarta: Kemendiknas. (2010)

[9] Trianto: Mengembangkan Model Pembelajaran Tematik. Prestasi Pustaka Publisher, Jakarta (2010)

[10] Wahyuni, A., Tias, A. A. W.., Sani, B: 2013. Peran Etnomatematika dalam Membangun Karakter Bangsa. Penguatan Peran Matematika dan Pendidikan Matematika untuk Indonesia yang Lebih Baik, P-15: 113-118. (2013)

[11] Kusmiarsih, A. M., \& Halida: 2013. Pengembangan Karakter Semangat Kebangsaan Melalui Metode Tanya Jawab Dengan Media Gambar Di Sekar Melati. Jurnal Untan. jurnal.untan.ac.id/index.php/jpdpb/article/download/3501/3541

[12] Lestyarini B: Penumbuhan Semangat Kebangsaan Untuk Memperkuat Karakter Indonesia Melalui pembelajaran Bahasa. Vol. 2(3) pp. 340-354. Jurnal Pendidikan Karakter (2012)

[13] Zafirah, A., Agusti, F.A., Engkizar, A. F., Alwi, A.F., \& Ernawati: Penanaman NilaiNilai Karakter Terhadap Peserta Didik Melalui Permainan Congklak Sebagai Media Pembelajaran. Vol. 8(1), pp. 95-104. Jurnal Pendidikan Karakter (2018) 
[14] Indriati, D.: Meningkatkan Hasil Belajar IPA Konsep Cahaya Melalui Pembelajaran Science Edutainment Berbantuan Media Animasi. Vol. 1(2) pp. 192-197. Jurnal Pendidikan IPA Indonesia (2012)

[15] Asriati, N.: Mengembangkan Karakter Peserta Didik Berbasis Kearifan Lokal Melalui Pembelajaran di Sekolah. Vol. 3(2). Jurnal Pendidikan Sosiologi dan Humaniora (2012)

[16] Wanabuliandari, S., \& Purwaningrum, J. P.: Pembelajaran Matematika Berbasis Kearifan lokas Gusjigang Kudus Pada Siswa Slow learner. Vol. 7(1). Eduma : Mathematics Education Learning And Teaching (2018)

[17] Wanabuliandari, S.: Pengenalan Budaya Lokal Kota Kudus Melalui Pembelajaran Etnomatematika Pada Anak Usia Dini. Prosiding Seminar Nasional: Implementasi Bimbingan dan Konseling pada Lembaga pendidikan Anak Usia Dini Dalam Rangka Peningkatan Kualitas Pendidik dan Tenaga Kependidikan Pendidikan Anak Usia Dini. ISBN :978-602-1180-38-9, hal 40-53. (2016) 